\title{
Diversity of freshwater red algae at Khao Luang National Park, southern Thailand
}

\author{
W. Chankaew ${ }^{1, *}$, A. Sakset ${ }^{2}$, S. Chankaew ${ }^{3}$, E. K. Ganesan ${ }^{4}$, Orlando Necchi Jr. ${ }^{5}$ and John \\ A. West ${ }^{6}$
}

${ }^{1}$ Department of Fisheries, Faculty of Agriculture, Rajamangala University of Technology Srivijaya, Nakhon Si Thammarat, 80000, Thailand

${ }^{2}$ Inland Fisheries Research and Development Center Region 5 (Surat Thani), Surat Thani, 84130, Thailand

${ }^{3}$ Faculty of Science and Technology, Nakhon Si Thammarat Rajabhat University, Nakhon Si Thammarat, 80000, Thailand

${ }^{4}$ Instituto Oceanográfico, Universidad de Oriente, Cumaná,6101, Venezuela

${ }^{5}$ Department of Zoology and Botany, São Paulo State University, S. Jose Rio Preto, São Paulo, 15054-000, Brazil

${ }^{6}$ School of Biosciences 2, University of Melbourne, Parkville, VIC 3010, Australia

Freshwater red algal diversity and the relationship with water conditions in 22 stream segments in the area around Khao Luang National Park, Nakhon Si Thammarat province, southern Thailand, were studied during a period of twelve months (May 2014 to April 2015). Sixteen species of freshwater red algae, belonging to eight genera (Audouinella, Balliopsis, Batrachospermum, Caloglossa, Compsopogon, Kumanoa, Sirodotia, and Thorea) were identified, which were all reported earlier for the country. Thorea clavata (Thoreaceae) was the most common species occurring in eight stream segments. Caloglossa beccarii sensu lato (Delesseriaceae) and Sirodotia huillensis Skuja (Batrachospermaceae) had the highest percent cover with up to $40 \%$ and $20 \%$ per stream segment, respectively. The water quality showed most sites to be unpolluted or ultra-oligotrophic to oligotrophic. Canonical Correspondence Analysis revealed some trends in occurrence of individual species with stream environmental variables: Batrachospermum sp. with strong current velocity; Kumanoa hirosei with high turbidity, total dissolved solid and alkalinity; Caloglossa beccarii with high conductivity; Kumanoa tabagatenensis with high ammonia-nitrogen and Thorea siamensis with high calcium and magnesium. In view of the scarce studies on the stream ecology of freshwater red algae in Philippines and neighbouring countries, it is expected that the data presented here would be helpful in more critical further studies in south-east Asia in general.

Key Words: Audouinella; Balliopsis; Batrachospermum; biodiversity; Caloglossa; Compsopogon; environmental factors; Kumanoa; Sirodotia; Thorea

\section{INTRODUCTION}

Freshwater red algae constitute only about $3.4 \%$ of the total number of members of the division Rhodophyta, while the remaining more than $96.6 \%$ are exclusively marine (Sheath 1984, Guiry and Guiry 2017). The envi- ronmental physical and chemical conditions are considerably different spatially and temporally from those of the marine environment (Necchi et al. 1999). Red algal diversity and ecology in characteristics in freshwaters are

\section{(ब) (1) $\Theta$}

This is an Open Access article distributed under the terms of the Creative Commons Attribution Non-Commercial License (http://creativecommons.org/licenses/by-nc/3.0/) which permits unrestricted non-commercial use, distribution, and reproduction in any medium, provided the original work is properly cited.
Received June 3, 2018, Accepted November 30, 2018

* Corresponding Author

E-mail: wanninee81749@gmail.com

Tel: +66-089-648-1749, Fax: +66-075-329-936 


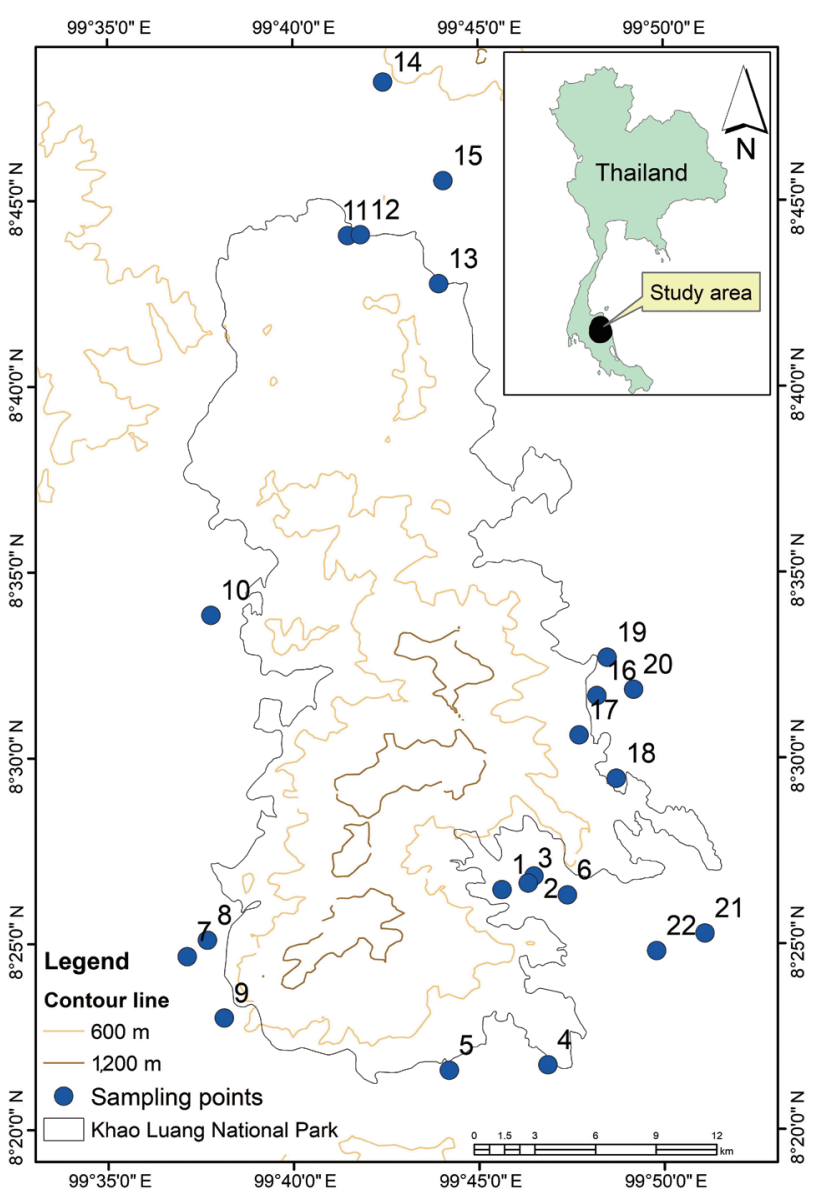

Fig. 1. Map of Thailand showing the location of the study areas around Khao Luang National Park, Nakhon Si Thammarat province, Thailand.

diverse. Sheath (1984) and Sheath and Hambrook (1990) evaluated on large scale (biomes and continent), the biology, ecology, and taxonomy of freshwater red algae. Primary studies of the ecology, distribution and diversity of freshwater red algae have been conducted in Rhode Island, USA by Burkholder and Sheath (1985), Sheath and Burkholder (1985), Sheath et al. (1986), in Brazil by Nec- chi (1993), Necchi et al. (1999), and in Europe by Eloranta and Kwandrans (1996, 2004). Malaysia has high red algal diversity with many endemic taxa, (Johnston et al. 2014). Only a few investigations of freshwater macroalgal ecology have been published in South East Asia. In Thailand, ecological studies have been conducted on water quality and its effects on the distribution and diversity of phytoplankton and benthic algae in Doi Suthep-Pui National Park (Peerapornpisal et al. 2000). Studies were performed to determine phytoplankton bio-indicators in Ang-Kaew reservoir by Peerapornpisal et al. (2004) and macroalgal / phytoplankton diversity as bio-monitors of water quality by Suphan and Peerapornpisal $(2003,2007)$. Red algal diversity and ecology have been investigated by Chankaew et al. (2013, 2015), Peerapornpisal et al. (2006), Traichaiyaporn et al. $(2004,2005,2007)$, and Naulcharoen et al. (2007). More recently, Chankaew et al. (2016) evaluated the importance of two freshwater red algae (Caloglossa ogasawarensis and Compsopogon caeruleus as C. aeruginosus) as potential candidates for development of antioxidants. The aims of the present study are to describe the diversity and abundance of freshwater red algae and their relation to environmental factors in stream segments around an important area in southern Thailand, the Khao Luang National Park. The data presented here will be a useful source of information for further studies on the ecology of the freshwater red algae in lotic water bodies of other areas of Thailand and the Southeast Asian region.

\section{MATERIALS AND METHODS}

\section{Area of study}

Khao Luang National Park (Nakhon Si Thammarat province) (Fig. 1), is an important watershed region for the surrounding farms and villages, located between the following geographic coordinates: $08^{\circ} 30^{\prime} \mathrm{N}, 99^{\circ} 44^{\prime} \mathrm{E}$. Cov-

Table 1. Sampling stations from districts, around Khao Luang National Park, Nakhon Si Thammarat province, Thailand

\begin{tabular}{ll}
\hline Station & \multicolumn{1}{c}{ Location } \\
\hline K1-K6 & LanSaKa district; Wangbaipat, Klong Toog, Lumnga, Nongkaew, Cheesuk and Wangpai streams \\
K7-K8 & ChangKlang district; Klongtow and Klongpeeg streams \\
K9 & Phipoon district; Nannokan stream \\
K10 & Chawang district; Suanei stream \\
K11-K15 & Nopphitum district; Pakklong, Krungching, Klongyan, Klongka and Klonggun streams \\
K16-K20 & Promkhiri district; Huaytaykaw, Plauyoen, Plauynam, Promlok and Nogta streams \\
K21-K22 & Mueang district; Huaymoo and Huayhang streams \\
\hline
\end{tabular}

See Fig. 1 for location of each station. 
ering an area of approximately $570 \mathrm{~km}^{2}$, it is mountainous with many tall peaks and has forests, wildlife, rivers and waterfalls (National Park, Wildlife and Plant Conservation Department 2006). Due to its unique location on the peninsula, it receives heavy monsoon rains throughout the year from both the east and the west coasts. The climate is tropical, with well-demarcated rainy and dry seasons. We selected 22 stream segments accessible by car around community areas of seven different districts of Nakhon Si Thammarat province in Khao Luang National Park (designated K1 to K22) (Table 1).

\section{Environmental (physical and chemical) water variables and red algal sampling}

Physical and chemical stream variables were measured and two replicates of each alga were collected at each site in each of three seasons over a period of 12 months (May 2014 to April 2015): the early rainy season (July-August 2014, SW monsoon), the heavy rainy (November-December 2014, NE monsoon), and the dry season (March-April 2015). Species exploring were conducted along a transect line marked by permanent plots. A long-transect length surveyed is $100 \mathrm{~m}$ per sampling site. In each of the 22 sites, a permanent plot $10 \mathrm{~m}$ in length along the stream margin was used as the sampling area were chosen at random (modified from Necchi 1993, Necchi et al. 1999). Along this $10 \mathrm{~m}$ long transect, divided into 10 at equal intervals, red algal occurrence (presence and percent cover) was estimated visually on the stream bottom and abundance was averaged over the entire stream segment according to the following scale (modified from Necchi 1993): 0 , absent; $1,<10 \%$; $2,11-20 \% ; 3,21-30 \%$; 4 , 31-40\%; 5 , $>40 \%$. This procedure was followed in two replicates in each site and data were computed as the average for the sampling site.

In each study site, water samples were collected for measurement according to American Public Health Association, American Water Works Association, and Water Pollution Control Pact standards (Eaton et al. 1995). Temperature, water depth, current velocity, conductivity, total dissolved solid, dissolved oxygen (DO), and $\mathrm{pH}$ values were measured in the field using standard portable instruments (Portable Multi Parameter Photometer, MD600; Lovibond, Dortmund, Germany). Nutrients, ammonium-nitrogen $\left(\mathrm{NH}_{3}-\mathrm{N}\right)$, nitrate-nitrogen $\left(\mathrm{NO}_{3}\right.$ $\mathrm{N})$, and orthophosphate $\left(\mathrm{PO}_{4}-\mathrm{P}\right)$, acidity, alkalinity, and hardness were analyzed in the laboratory by standard methods (Eaton et al. 1995) from water samples kept at $4^{\circ} \mathrm{C}$ until analysis. The trophic status was evaluated us- ing the Applied Algal Research Laboratory Physical and Chemical score (AARL-PC score) (Peerapornpisal et al. 2004). This composite index defines water quality categories using dissolved oxygen, conductivity, nitratenitrogen, ammonia-nitrogen, and soluble reactive phosphorus (SRP).

Algal specimens were preserved in $2 \%$ glutaraldehyde in the field. Species were identified using morphological characters according to Jose and Patel (1990), Kumano (2002), Traichaiyaporn et al. (2007, 2012), Necchi and Vis (2012), and Necchi (2016). The community structure was evaluated using the Shannon-Wiener diversity index $\left(H^{\prime}\right)$ and Pielou's evenness index $\left(J^{\prime}\right)$ (Brower et al. 1997). These indices were calculated from the annual average scores of red algal species records. Shannon-Wiener diversity $-\sum_{n=1}^{n} p i \log _{2} p i$ with $i$ proportion of each algal species (percent cover) to the total abundance, Pielou's evenness $=H^{\prime} / H_{\max }$, where $H^{\prime}=$ Shannon-Wiener diversity index, $p i=$ the proportion of individual average scores of the species $i^{\text {th }}$ species expressed as a proportion of total abundance, $H_{\max }=\log _{2} \mathrm{~S}$, where $\mathrm{S}=$ the total number of species.

\section{Statistical analysis}

Univariate analysis, using the mean and standard deviation, was applied to describe and evaluate the water quality among sampling sites and seasons. Multivariate indices analysis, cluster and ordination multi-dimensional scaling (MDS) analyses were used to classify similarity of water quality parameters among seasons and sites. The cluster and MDS analyses aimed to find grouping of similarities of samples among different sites and season that samples within a group are more similar to each other than samples in different groups. The resulting cluster was shown in tree-like diagram called a dendrogram and MDS was shown as biplot. The correspondence of the ordination to the distances shown as a stress value, where a value less than 0.05 is an excellent fit, a value less than 0.10 is a good fit, a value less than 0.20 is a potential fit and a value greater than 0.30 is an arbitrary fit. Both the clustering dendrogram and map were constructed using a standardized Euclidean distances matrix for the water variables. Analysis of similarity (ANOSIM) was also performed to determine significant differences in the different groups of water parameters. The similarity percentages (SIMPER) was used to test the parameters within groups. All analysis procedures used were based on Clark and Warwick (1994) using PRIMER program (ver. 5 for Windows; Bourne Press Limited, Bournemouth, 

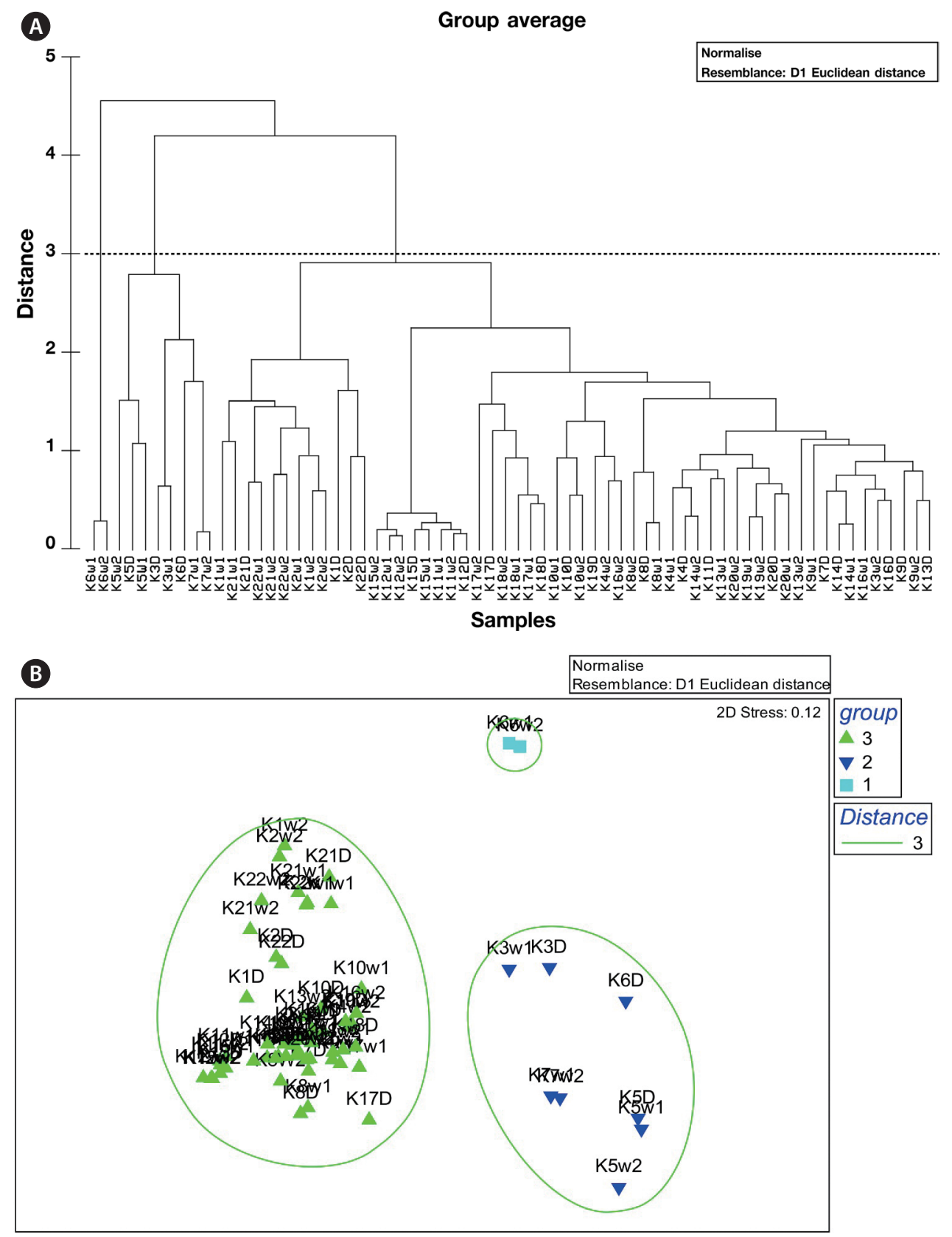

Fig. 2. Normalized Euclidean cluster diagram (A) and multi-dimensional scaling analyses (B) according to sampling sites of physico-chemical variable in all seasons.

UK). The relationships between red algae assemblages and environment variables were explored by Canonical Correspondence Analysis (CCA) using MVSP (MultiVariate Statistical Package) for Windows ver. 3.22. The result was shown by CCA plot.

In addition, the trophic status of water was evaluated from the main parameters such as dissolved oxygen, conductivity, ammonia-nitrogen, nitrate-nitrogen and SRP by AARL-PC score, based on Peerapornpisal et al. (2004).

\section{RESULTS AND DISCUSSION}

\section{Environmental factors}

Most stream segments (20 of 22) were slightly acidic (pH $6.3 \pm 0.2$ to $6.7 \pm 0.6$ ) while two stream segment (K5 and K9) were slightly basic (pH $7.4 \pm 0.5$ and $7.1 \pm 1.2$ ), with high DO content ( $3.51 \pm 1.5$ to $\left.7.8 \pm 0.7 \mathrm{mg} \mathrm{L}^{-1}\right)$ and conductivity levels $\left(12.4 \pm 10.1\right.$ to $\left.128.3 \pm 24.4 \mu \mathrm{sm}^{-1}\right)$. All 
stream sites had clear water with low turbidity (except K6 site) and relatively high water temperature (varied from $24.5 \pm 0.4$ to $26.5 \pm 0.6^{\circ} \mathrm{C}$ ). The current velocity was highly variable, ranging from $2.0 \pm 0.1$ to $116.5 \pm 22.2 \mathrm{~cm} \mathrm{~s}^{-1}$. The turbidity ranged from $1.0 \pm 0.1$ to $116.5 \pm 22.2$ nephelometric turbidity unit. Total dissolved solids (TDS) ranged from $6.4 \pm 1.1$ to $58.4 \pm 20.2 \mathrm{mg} \mathrm{L}^{-1}$. In acid samples $\mathrm{CaCO}_{3}$ varied from $2.3 \pm 0.3$ to $19.8 \pm 4.4 \mathrm{mg} \mathrm{L}^{-1}$. In alkaline samples alkalinity is accurately expressed as $\mathrm{CaCO}_{3}$, which was $4.3 \pm 1.5$ to $81.3 \pm 0.8 \mathrm{mg} \mathrm{L}^{-1}$. In a wide range of samples hardness as $\mathrm{CaCO}_{3}$ varied from $5.1 \pm 0.8$ to $130.8 \pm$ $59.6 \mathrm{mg} \mathrm{L}^{-1}$. Ammonia-nitrogen values varied from $<0.02$ \pm 0.0 to $0.22 \pm 0.1 \mathrm{mg} \mathrm{L}^{-1}$ (Table 2).

Most species occurred in slightly acidic water, which is consistent with data from Sheath and Hambrook (1990), who reported freshwater red algae occurring mostly in mildly acidic streams ranging between $\mathrm{pH} 6.0$ and 7.0. The AARL-PC showed most sites within the range of ultraoligotrophic to oligotrophic status, and few in the oligomesotrophic (Table 3). Most of the sampling sites showed similar trophic status throughout the year and were classified to clean to very clean. This finding is probably due to geographical proximity of the preserved area of Khao Luang National Park. However, the sampling sites K2, K4, $\mathrm{K} 5, \mathrm{~K} 14$, and K22 located in the downstream area showed moderate contamination levels by the agriculture activities, evidenced by oligo-mesotrophic status (clean to moderate clean). These characteristics were similar to those described in eight National parks of five provinces in northern Thailand (Traichaiyaporn et al. 2005).

Cluster and MDS analyses of water quality parameter variations among seasons and sites showed three groups. The three groups ( $70 \%$ similarity and ANOSIM test results of $\mathrm{R}=0.977, \mathrm{p}<0.01$ ) were group $1-\mathrm{K} 6 \mathrm{~W} 1$ and $\mathrm{K} 2 \mathrm{~W} 2$, group 2-K3D, K3W1, K5D, K5W1, K5W2, K6D, K7W1, and K7W2, and group 3 composed of the rest of the sampling dates (56 variables) (Fig. 2A \& B). One parameter indicated similarity within each groups: turbidity contributed greater than $15 \%$ similarity in the first group; TDS, hardness and velocity in the second group; TDS and conductivity in the third group. The status of Khao Luang National Park water quality is similar to the results of Thiemdoa et al. (2007) in other areas of northern and southern Thailand with mostly clean waters.

\section{Species composition and distribution}

A total of 16 red algal species were identified (Table 4), belonging to eight genera Audouinella, Balliopsis, Batrachospermum, Caloglossa, Compsopogon, Kumanoa,
Sirodotia, and Thorea) that are distributed among the families Acrochaetiaceae, Batrachospermaceae, Compsopogonaceae, Delesseriaceae, and Thoreaceae, and occurred in all collecting sites sampled (Table 3). In 16 sites only one species was found, whereas site K5 had the highest species richness with four species (Table 3). The most species-rich genera recorded was Kumanoa (four species), followed by Sirodotia (three species), and Thorea (two species). Audouinella, Balliopsis, Caloglossa, and Compsopogon has only one species. Thorea clavata Seto \& Rathanasabapathy occurred most frequently in eight sites in both seasons, while most appeared rarely (only 1 site). During this study, maximum algal abundance was observed in April 2015 at the Klonggun site (K15), in which the dominant species was Caloglossa beccarii (Zanardini) De Toni sensu lato. The lowest algal abundance was found in Klongtow site (K7), in which Audouninella subtilis Jao occurred in both seasons. The highest species richness was at the Klongwangpai site (K6) with four species, while at 11 sites only one species was found. Among the 16 species sampled, $T$. clavata and C. beccarii sensu lato were dominant with greatest abundance and maximum density, respectively. In contrast, some species were found only in particular sites, for instance, A. subtilis occurred only at Klong tow (K7), Thorea siamensis was observed only at the Huaycheesuk (K5) and Kumanoa gibberosa occurred only at the Huaytrankaew (K16) (Table 3). Our results show the streams around Khao Luang National Park have a high diversity of red algae compared to studies of other regions of the world (Necchi et al. 1999, Eloranta et al. 2016). This area is well-preserved and has relatively rich red algal communities, when compared with some neighbouring countries like Philippines (Liao 2010), Malaysia and Indonesia (Johnston et al. 2014).

It is also important to point out that the alga we have identified tentatively as $C$. beccarii sensu lato as occurring in Thailand, well in the morphological characteristics of Caloglossa fluviatilis, a species described from Panama and also reported from India (Kamiya and West 2014). However, molecular characterization of the Thailand specimens are under study to confirm our tentative identification.

\section{Comparison of dry and rainy seasons}

Table 3 shows some differences in diversity of study sites and seasons. Of the 22 sites surveyed, eight species were found in all seasons. The highest values (16) of species richness were observed in the period of dry and wet 


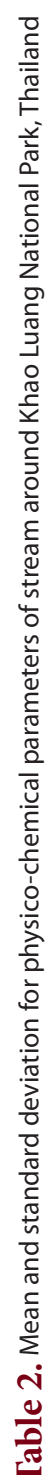

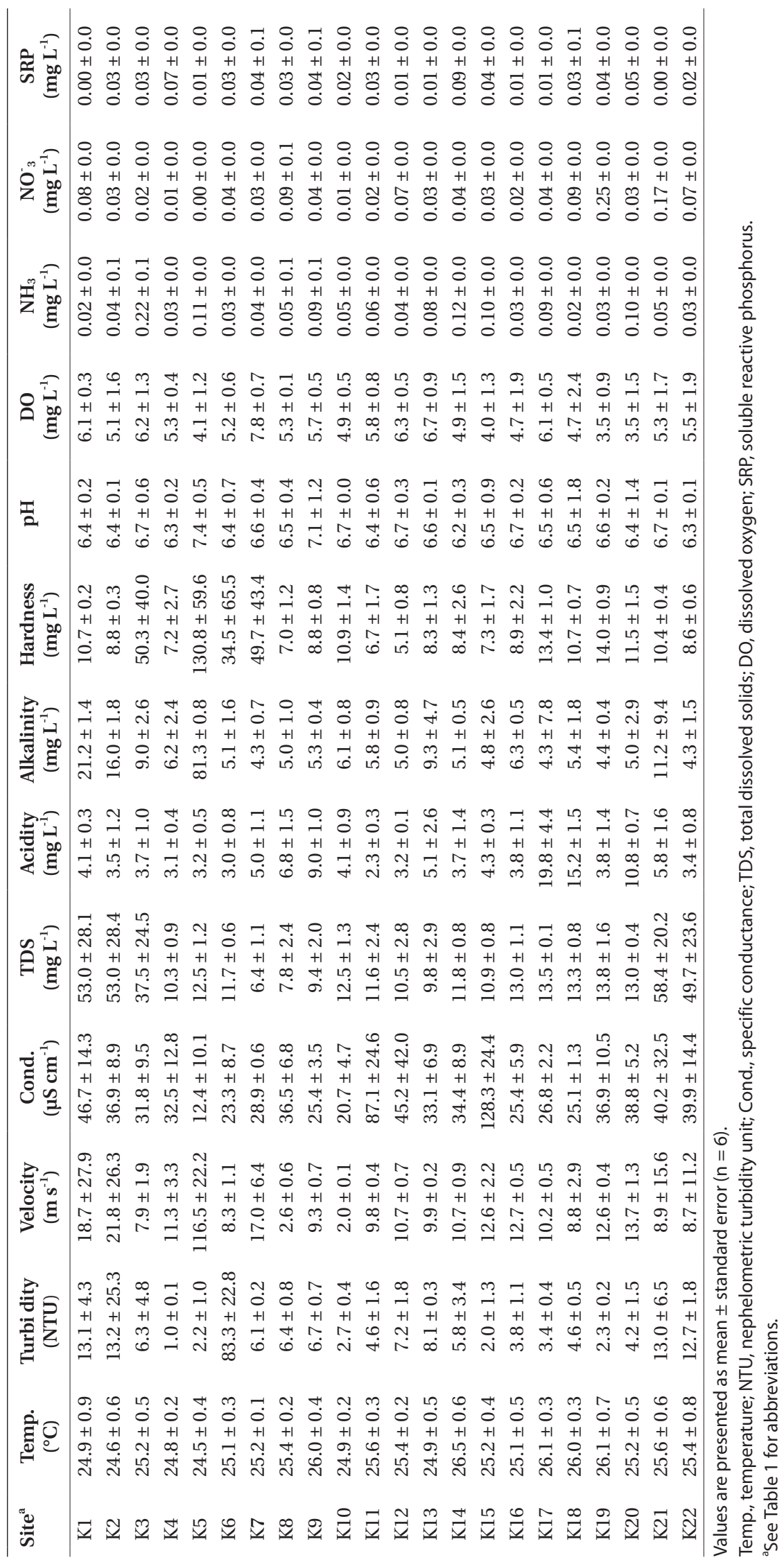


Table 3. Species number, Shannon-Wiener index, Simpson index, and Pielou evenness and water quality by trophic status for the different sampling sites

\begin{tabular}{|c|c|c|c|c|c|c|}
\hline \multirow{2}{*}{ Site $^{\mathrm{a}} /$ Diversity index } & \multicolumn{3}{|c|}{ No. of species } & \multicolumn{3}{|c|}{ Trophic status } \\
\hline & W1 & W2 & D & W1 & W2 & D \\
\hline K1 & 1 & 1 & 1 & UO & UO & $\mathrm{O}$ \\
\hline K2 & 1 & 1 & 1 & UO & $\mathrm{O}$ & $\mathrm{OM}$ \\
\hline K3 & 0 & 1 & 1 & UO & UO & $\mathrm{O}$ \\
\hline K4 & 1 & 1 & 1 & UO & $\mathrm{O}$ & $\mathrm{OM}$ \\
\hline K5 & 4 & 3 & 1 & $\mathrm{O}$ & $\mathrm{O}$ & $\mathrm{OM}$ \\
\hline K6 & 3 & 2 & 1 & UO & UO & $\mathrm{O}$ \\
\hline K7 & 2 & 2 & 1 & UO & UO & $\mathrm{O}$ \\
\hline K8 & 1 & 1 & 2 & UO & $\mathrm{O}$ & $\mathrm{O}$ \\
\hline К9 & 1 & 1 & 1 & UO & UO & $\mathrm{O}$ \\
\hline K10 & 1 & 0 & 1 & UO & $\mathrm{O}$ & $\mathrm{O}$ \\
\hline K11 & 3 & 3 & 2 & UO & UO & $\mathrm{O}$ \\
\hline K12 & 1 & 1 & 1 & $\mathrm{O}$ & $\mathrm{O}$ & $\mathrm{O}$ \\
\hline K13 & 1 & 1 & - & UO & UO & $\mathrm{O}$ \\
\hline K14 & 1 & 0 & 1 & UO & $\mathrm{O}$ & $\mathrm{OM}$ \\
\hline K15 & 1 & 1 & 1 & UO & UO & $\mathrm{O}$ \\
\hline K16 & 2 & 2 & 1 & UO & UO & $\mathrm{O}$ \\
\hline K17 & 1 & 1 & 1 & UO & UO & $\mathrm{O}$ \\
\hline K18 & 2 & 1 & 2 & UO & UO & $\mathrm{O}$ \\
\hline K19 & 1 & 0 & 1 & UO & UO & $\mathrm{O}$ \\
\hline K20 & 1 & 1 & 1 & UO & $\mathrm{O}$ & $\mathrm{O}$ \\
\hline K21 & 1 & 0 & 1 & $\mathrm{O}$ & $\mathrm{O}$ & $\mathrm{O}$ \\
\hline K22 & 1 & 1 & 2 & $\mathrm{OM}$ & $\mathrm{OM}$ & $\mathrm{OM}$ \\
\hline Shanon-Wiener index & 3.793 & 3.010 & 3.797 & - & - & - \\
\hline Simpson index & 0.915 & 0.875 & 0.916 & - & - & - \\
\hline Pielou evenness & 0.945 & 1.0 & 0.946 & - & - & - \\
\hline
\end{tabular}

W1, wet season (SW); W2, wet season (NE); D, dry season; UO, ultraoligotrophic; O, oligotrophic; OM, oligotrophic-mesotrophic.

${ }^{\mathrm{a}} \mathrm{See}$ Table 1 for abbreviations.

Table 4. List of stream red algae, site distribution and abundance (\%) in stream around KhaoLuang National Park, Nakhon Si Thammarat province

\begin{tabular}{|c|c|c|c|c|c|}
\hline \multirow{2}{*}{ Order / Family } & \multirow{2}{*}{ Genus / Species } & \multirow{2}{*}{ Site distribution $^{\mathrm{a}}$} & \multicolumn{3}{|c|}{ Abundance $(\%)^{\mathrm{b}}$} \\
\hline & & & W1 & W2 & D \\
\hline $\begin{array}{l}\text { Acrochaetiales / } \\
\text { Acrochaetiaceae }\end{array}$ & Audouinella subtilis $\mathrm{Jao}^{\mathrm{c}}$ & K7 & 1 & 1 & 1 \\
\hline Batrachospermales / & Balliopsis prieurii (Montagne) G. W. Saunders et Necchi & K9 & 1 & 1 & 1 \\
\hline \multirow[t]{10}{*}{ Batrachospermaceae } & $\begin{array}{l}\text { Batrachospermum khaoluangensis Chankaew, Peer- } \\
\text { apornpisal et Kumano }\end{array}$ & K5 & 1 & 1 & 1 \\
\hline & Batrachospermum gelatinosum (L.) Roth & K19 & 1 & 0 & 1 \\
\hline & Batrachospermum sp.1 & $\mathrm{K} 8,10$ & 1 & 0 & 1 \\
\hline & Kumanoa gibberosa (Kumano) Necchi et M. L. Vis & K16 & 1 & 1 & 1 \\
\hline & Kumanoa hirosei (Kumano) Necchi et M. L. Vis & K6, 21 & 1 & 1 & 1 \\
\hline & $\begin{array}{l}\text { Kumanoa mahlacensis (Kumano et W. A. Bowden- } \\
\text { Kerby) M. L. Vis, Necchi, W. B. Chiasson et Entwisle }\end{array}$ & $\mathrm{K} 11,18$ & 1 & 0 & 1 \\
\hline & $\begin{array}{l}\text { Kumanoa tabagatenensis (Kumano et W. A. Bowden- } \\
\text { Kerby) M. L. Vis, Necchi, W. B. Chiassont et Entwisle }\end{array}$ & K22 & 1 & 0 & 1 \\
\hline & Sirodotia huillensis (W. West et G. S. West) Skuja & K6 & 1 & 1 & 1 \\
\hline & Sirodotia suecica Kylin & $\mathrm{K} 2,4$ & 1 & 0 & 1 \\
\hline & Sirodotia sp.1 & K14 & 1 & 0 & 1 \\
\hline $\begin{array}{l}\text { Compsopoganales / } \\
\text { Compsopogonaceae }\end{array}$ & Compsopogon caeruleus (Balbis) Montagne & $\mathrm{K} 5,8,17,20$ & 1 & 0 & 1 \\
\hline $\begin{array}{l}\text { Ceramiales / } \\
\text { Delesseriaceae }\end{array}$ & Caloglossa beccarii (Zanardina) De Toni sensu lato $^{\mathrm{d}}$ & $\mathrm{K} 11,12,15$ & 2 & 1 & 2 \\
\hline \multirow[t]{2}{*}{ Thoreales / Thoreaceae } & Thorea clavata Seto et Ratnas & $\mathrm{K} 1,3,5,6,7,11,13,18$ & 4 & 1 & 4 \\
\hline & Thorea siamensis Kumano et Traichaiyaporn & K5 & 1 & 0 & 1 \\
\hline
\end{tabular}

W1, wet season (SW); W2, wet season (NE); D, dry season.

${ }^{a}$ See Table 1 for abbreviations.

${ }^{b} 0$, absent; $1,<10 \% ; 2,11-20 \% ; 3,21-30 \% ; 4,31-40 \%$.

'Possibly only a 'Chantransia' stage of Batrachospermumales.

${ }^{\mathrm{d}}$ A complex of four species including Caloglossa fluviatilis Krayesky, Fredericq \& J. N. Norris (see key in Sato and Akiyama 2001, Kamiya et al. 2016). We tentatively identify our specimens as $C$. beccarii sensu lato, pending critical morphological and molecular studies of the Thai populations. 


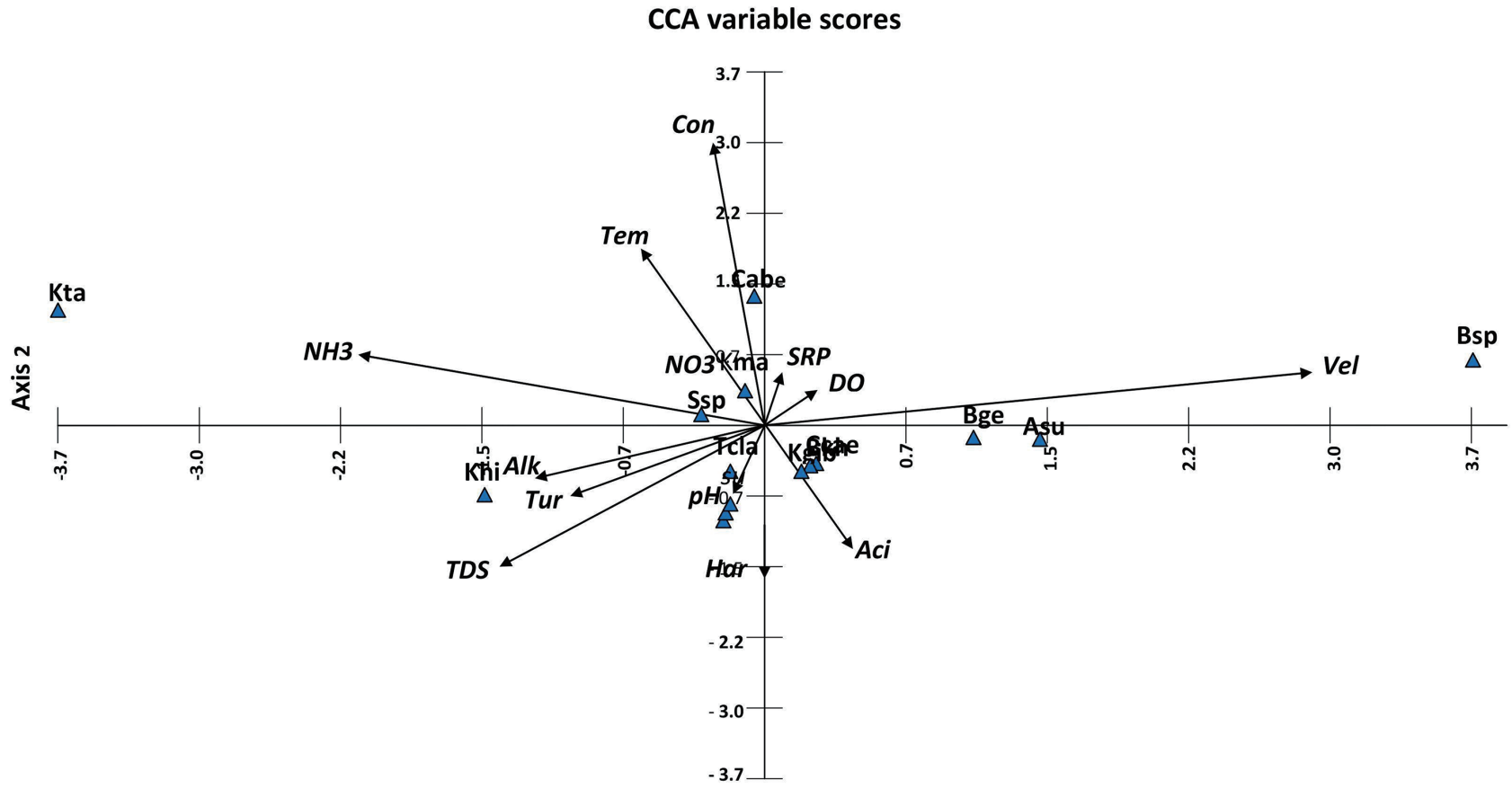

Vector scaling 3.96

Axis 1

Fig. 3. Canonical Correspondence Analysis (CCA) plot showing the relationship among water quality variables, sampling sites and freshwater red algae. Eigenvalues and percentage of variance of axes 1 and 2 are 0.73 and $0.66 ; 8.23$ and 7.45; 8.23, respectively. Aci, acidity; Alk, alkalinity; Asu, Audouinella subtilis; Bge, Batrachospermum gelatinosum; Bsp, Batrachospermum sp.; Cabe, Caloglossa beccarii; Con, conductivity; DO, dissolved oxygen; Har, hardness; Khi, Kumanoa hirosei; Kma, Kumanoa mahlacensis; Kta, Kumanoa tabagatenensis; $\mathrm{NH}_{3}$, ammonia-nitrogen; $\mathrm{NO}_{3}$, nitrate-nitrogen; SRP, soluble reactive phosphorus; Ssp, Sirodotia sp.; Tcla, Thorea clavata; TDS, total dissolved solids; Tem, temperature; Tur, turbidity; Vel, velocity.

season of early rainy season SW monsoon (16 species), whereas the lowest numbers occurred in wet season of heavy rainy season (8 species). The highest diversity values revealed by Shannon-Wiener, Simpson and Pielou indices were observed in dry season (when the dominant species was C. beccarii sensu lato) (Table 3). In the dry season other common species were Compsopogon caeruleus, Audouinella subtilis, Kumanoa tabagatenensis, Sirodotia huillensis, S. suecica, Thorea clavata, T. siamensis, and Balliopsis prieurii, which were found in all seasons with variable abundances. The highest values of species richness and abundance of red algae observed in the dry season could be due to the higher sunlight irradiance and light penetration in water with lower turbidity increasing photosynthesis, as well as slow current velocity allowing increased biomass, as reported in temperate regions (Sheath 1984) and tropical regions (Necchi 1993). In addition, nutrient run off during the rainy season, especially in NE monsoon, might influence algal growth and abundance. Of all the species surveyed, Caloglosssa beccarii sensu lato, is of special interest, since it had the highest abundance in all seasons. This might be due to their small thallus size (about $2 \mathrm{~cm}$ high) coupled with production of new blades, adventitious branches from blade margins and firm attachment by rhizoids. At present in Thailand freshwater Caloglossa species identification is not clear for lack of critical comparative molecular and morphological characterizations. Two species of Caloglossa, C. beccarii (Sato and Akiyama 2002) and C. leprieurii (Montagne) G. Martens (Peerapornpisal et al. 2006, Naulcharoen et al. 2007), have been reported from southern Thailand, the latter species from a peat swamp in Krabi province. The former species has a wide distribution in freshwater streams from Southeast Asia being reported recently from Indonesia and Malaysia (Johnston et al. 2014). As already stated, following recent papers (Kamiya and West 2014, West et al. 2015, Kamiya et al. 2016) we tentatively identified, but based on only on morphological studies, the Thailand specimens as C. beccarii sensu lato, but they seems to belong to a different species (C. fluvaitilis). 


\section{Relationship between red algal abundance and environmental variables by CCA}

Many environmental variables can influence the growth of freshwater red algae. The substrate characteristics have a direct impact on the distribution of these algae (Sheath 1984), whereas other environmental factors affect stream condition and freshwater algal seasonality. In this study, water quality and trophic status were not particularly different among study sites and seasons. In a period of high turbidity, especially during the North-East monsoon, the nutrient concentration increased, water transparency decreased and species richness was lower (8 species). In this aspect, it is similar to a study made in Brazil (Necchi 1993), where algal abundance decreased with a higher nutrient levels, solar radiation, temperature and turbidity.

The relationship of red algae and water quality parameters provided by CCA plot (Fig. 3), indicated that the abundance of Batrachospermum sp. (Bsp) was positively correlated with current velocity (Vel) but it was negatively correlated with TDS, turbidity, and alkalinity. Thus, this species is more abundant in higher water velocity and lower TDS, turbidity, and alkalinity. Caloglossa beccarii sensu lato was more abundant in higher conductivity and temperature and lower $\mathrm{pH}$. Kumanoa tabagatenensis was more abundant in high ammonia concentration and slightly acidic condition. Kumanoa hirosei was more abundant in higher alkalinity, turbidity and TDS with lower DO and SRP. Although the dominant taxon, C. beccarii sensu lato occurred in three sites at all seasons under oligotrophic-mesotrophic status based on AARLPC score. The presence of rare species of Batrachospermum and Kumanoa at most sites could also be relate to oligotrophic condition. These findings corroborate previous studies in Thailand (Suphan and Peerapornpisal 2003, 2007, Suphan et al. 2004, Peerapornpisal et al. 2006). The present trophic water data can provide a good basis for water management in Khao Luang National Park. Also, this research provides more information on freshwater red algal ecology in tropical streams.

\section{CONCLUSION}

A combined composition and ecological distribution study during a period of twelve months in 22 freshwater stream segments in southern Thailand resulted in the following conclusions: (1) sixteen species of freshwater red algae belonging to eight genera were identified show- ing a fairly rich diversity of freshwater red algal species; (2) water quality showed that most sites to be unpolluted (ultra-oligotrophic to oligotrophic); and (3) trend of individual species to occur in stream segments with particular environmental characteristics was evident as shown in Canonical Correspondence Analysis: Batrachospermum sp. with high current velocity; Kumanoa hirosei with high turbidity, total dissolved solids, and alkalinity; Caloglossa beccarii with high conductivity; Kumanoa tabagatenensis with high ammonia-nitrogen and Thorea siamensis with high calcium and magnesium.

\section{ACKNOWLEDGEMENTS}

This research is partially supported by Higher Education Research Promotion grants (HERP 2014; 2557 A17162012) "To participate in learning of ecology and biodiversity of freshwater red macroalgae, at community area around Khao Luang National Park, Nakhon Si Thammarat province, Thailand" and the field assistance by the students of the Fisheries Department, Faculty of Agriculture, Rajamangala University of Technology Srivijaya, Thailand, are gratefully acknowledged for support of this project.

\section{REFERENCES}

Brower, J. E., Zar, J. H. \& von Ende, C. N. 1997. Field and laboratory methods for general ecology. McGraw-Hill, New York, $273 \mathrm{pp}$.

Burkholder, J. M. \& Sheath, R. G. 1985. Characteristics of soft water streams in Rhode Island. 1. A comparative analysis of physical and chemical variables. Hydrobiologia 128:97-108.

Chankaew, W., Luaelae, W. \& Phromhom, S. 2016. Diversity and screening of biological activity of red macroalgae from Trang Watershed area, Thailand. Int. J. Agric. Technol. 12:2113-2122.

Chankaew, W., Peerapornpisal, Y., Kumano, S. \& Ngamriabsakul, C. 2013. A new species of Batrachospermum, B. khaoluangensis Chankaew, Peerapornpisal et Kumano, sp. nov. (Batrachospermales, Rhodophyta) from Thailand. Chiang Mai J. Sci. 40:1-10.

Chankaew, W., Sakset, A., Chankaew, S. \& Kumano, S. 2015. Possibility of freshwater red algae as bioindicator for water quality of streams in Nakhon Si Thammarat Province, Thailand. Int. J. Agric. Technol. 11:1349-1358.

Clarke, K. R. \& Warwick, R. M. 1994. Change in marine com- 
munity: an approach to statistical analysis and interpretation. Plymouth Marine Laboratory, Plymouth, 144 pp.

Eaton, A. D., Clesceri, L. S. \& Greenberg, A. E. 1995. Part 2000. Physical and aggregate properties. In American Public Health Association (Ed.) Standard Methods for the Examination of Water and Wastewater. American Public Health Association, Washington, DC, pp. 36-39.

Eloranta, P., Eloranta, A. \& Perämäki, P. 2016. Intensive study of freshwater red algae (Rhodophyta) in Finland. Fottea 16:122-132.

Eloranta, P. \& Kwandrans, J. 1996. Distribution and ecology of freshwater red algae (Rhodophyta) in some central Finnish rivers. Nord. J. Bot. 16:107-117.

Eloranta, P. \& Kwandrans, J. 2004. Indicator value of freshwater red algae in running waters for water quality assessment. Oceanol. Hydrobiol. Stud. 33:47-54.

Guiry, M. D. \& Guiry, G. M. 2017. AlgaeBase. World-wide electronic publication, National University of Ireland, Galway. Available from: http://www.algaebase.org. Accessed May 20, 2017.

Johnston, E. T., Lim, P. E., Buhari, N., Keil, E. J., Djawad, M. I. \& Vis, M. L. 2014. Diversity of freshwater red algae (Rhodophyta) in Malaysia and Indonesia from morphological and molecular data. Phycologia 53:329-341.

Jose, L. \& Patel, R. J. 1990. Caloglossa ogasawaraensis (Rhodophyta, Delesseriaceae), a freshwater Rhodophyceae new to India. Cryptogam. Algol. 11:225-228.

Kamiya, M. \&West, J. A. 2014. Cryptic diversity in the euryhaline red alga Caloglossa ogasawaraensis (Delesseriaceae, Ceramiales). Phycologia 53:374-382.

Kamiya, M., West, J. A., Karsten, U. \& Ganesan, E. K. 2016. Molecular and morphological delineation of Caloglossa beccarii related species (Delesseriaceae, Rhodophyta). Phycologia 55:640-649.

Kumano, S. 2002. Freshwater red algae of the world. Biopress Limited, Bristol, $375 \mathrm{pp}$.

Liao, L. M. 2010. Nomenclatural notes on some Philippine species of freshwater red algae (Rhodophyta). Philipp. J. Syst. Biol. 4:89-94.

National Park, Wildlife \& Plant Conservation Department. 2006. National parks in Thailand. National Park Office, Bangkok, 280 pp.

Naulcharoen, M., Sangkaew, C., Naulcharoen, P., Peerapornpisal, Y. \& Kumano, S. 2007. Diversity and distribution of freshwater red algae (Rhodophytes) in southern Thailand. J. Sci. Res. Chulalongkorn Univ. 6:95-105.

Necchi, O. Jr. 1993. Distribution and seasonal dynamics of Rhodophyta in the Preto River basin, southeastern Brazil. Hydrobiologia 250:81-90.

Necchi, O. Jr. 2016. Red algae (Rhodophyta) in rivers. In Nec- chi, O. Jr. (Ed.). River Algae. Springer, Cham, pp. 65-92.

Necchi, O. Jr., Branco, C. C. Z. \& Branco, L. H. Z. 1999. Distribution of Rhodophyta in streams from São Paulo State, southeastern Brazil. Arch. Hydrobiol. 147:73-89.

Necchi, O. Jr. \& Vis, M. L. 2012. Monograph of the genus Kumanoa (Rhodophyta, Batrachospermales). Bibl. Phycol. 116:1-79.

Peerapornpisal, Y., Chaiubol, C., Pekkoh, J., Kraibut, H., Chorum, M., Wannathong, P., Ngearnpat, N., Jusakul, K., Thammathiwat, A., Chuanunta, J. \& Inthasotti, T. 2004. The monitoring of water quality in Ang Kaew Reservoir of Chiang Mai University using phytoplankton as bioindicator from 1995-2002. Chiang Mai J. Sci. 31:85-94.

Peerapornpisal, Y., Nualcharoen, M., Suphan, S., Kunpradid, T., Inthasotti, T., Mungmai, R., Dhitisudh, L., Sukchotiratana, M. \& Kumano, S. 2006. Diversity and habitat characteristics of freshwater red algae (Rhodophytes) in some water resources of Thailand. ScienceAsia 32(Suppl. 1):63-70.

Peerapornpisal, Y., Pekthong, T., Waiyaka, P. \& Promkutkaew, S. 2000. Diversity of phytoplankton and benthic algae in Mae Sa Stream, Doi Suthep-Pui National Park, Chiang Mai. Nat. Hist. Bull. Siam Soc. 48:193-211.

Sato, H. \& Akiyama, H. 2002. Caloglossa beccarii (Ceramiales, Rhodophyta) from Thailand on the Malay Peninsula and its distribution in Southeast Asia. Nat. Hum. Act. 6:101-104

Sheath, R. G. 1984. The biology of freshwater red algae. Prog. Phycol. Res. 3:89-157.

Sheath, R. G. \& Burkholder, J. M. 1985. Characteristics of softxwater streams in Rhode Island. II. Composition and seasonal dynamics of macroalgal communities. Hydrobiologia 128:109-118.

Sheath, R. G., Burkholder, J. M., Hambrook, J. A., Hogeland, A. M., Hoy, E., Kane, M. E., Morrison, M. O., Steinman, A. D. \& Van Alstyne, K. L. 1986. Characteristics of softwater streams in Rhode Island. III. Distribution of macrophytic vegetation in a small basin. Hydrobiologia 140:183191.

Sheath, R. G. \& Hambrook, J. A. 1990. Mechanical adaptations to flow in freshwater red algae. J. Phycol. 24:107111.

Suphan, S. \& Peerapornpisal, Y. 2003. Use of macroalgae and benthic diatom to monitor water quality in the area of the Golden Jubilee Thong Pha Phum Project. Thong Pha Phum District, Kanjanaburi province, Thailand. In Proc. Int. Symp. Environ. Manage: Policy, Research \& Education, Chiang Mai.

Suphan, S. \& Peerapornpisal, Y. 2007. Diversity of macroalgae and benthic diatoms in the area of the Golden Jubilee Thong Pha Phum project, Thong Pha Phum dis- 
trict, Kanchanaburi province, Thailand. BRT Res. Rep. 2550:91-98.

Suphan, S., Peerapornpisal, Y. \& Kunpradid, T. 2004. Distribution of freshwater red algae genus Batrachospermum in some parts of Thailand. J. Sci. Res. Chulalongkorn Univ. 3:159-167.

Thiemdoa, S., Nualcharoen, P., Kumano, S., Boo, S. M., Suphan, S., Inthasotti, T. \& Peerapornpisal, Y. 2007. Diversity of freshwater red algae in water resources in northern and southern areas of Thailand. Sci. Res. Chulalongkorn Univ. 6:85-93.

Traichaiyaporn, S., Khuantrairong, T., Waraegsiri, B. \& Kumano, S. 2005. Two new records of freshwater red algae (Rhodophyta) in Thailand: Sirodotia huillensis (Welwitsch ex W. \& G. S. West) Skuja \& Sirodotia sinica Jao. In 31st Congr. Sci. Technol. Thail. Suranaree Univ. Technol, Thailand, pp. 1-3.

Traichaiyaporn, S., Kumano, S., Chainapong, T., Khuantrai- rong, T. \& Waraegsiri, B. 2004. New record of freshwater red algae (Rhodophyta) in Thailand: Batrachospermum mahlacense Kumano et Boden-Kerby. ScienceAsia 30:313-315.

Traichaiyaporn, S., Kumano, S. \&Waraegsiri, B. 2012. A freshwater red alga, Thorea clavata Seto et Ratnasabapathy, from Thailand with special reference to sexual reproductive organs. Maejo Int. J. Sci. Technol. 6:216-223.

Traichaiyaporn, S., Waraegsiri, B., Khuntrairong, T. \& Kumano, S. 2007. Environmental factors and biodiversity of some freshwater red algae (Rhodophyta) in Thailand: Mae Hong Son province. Sci. Res. Chulalongkorn Univ. 6:187-196.

West, J. A., Kamiya, M., Ganesan, E. K., Louiseaux-de Goër, S. \& Jose, L. 2015. Caloglossa beccarii (Delesseriaceae, Rhodophyta) from freshwater rivers in Kerala, India, a critical new record. Algae 30:207-216. 